\title{
Annual and spatial variabilities in the acorn production of Quercus mongolica
}

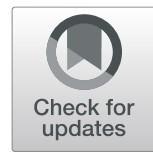

\author{
Jaesang Noh', Youngjin Kim², Jongsung Lee', Soyeon Cho ${ }^{1}$ and Yeonsook Choung ${ }^{1 *}$ (D)
}

\begin{abstract}
Background: Genus Quercus is a successful group that has occupied the largest area of forest around the world including South Korea. The acorns are an important food source for both wild animals and humans. Although the reproductive characteristics of this genus are highly variable, it had been rarely studied in South Korea. Therefore, in Seoraksan and Odaesan National Parks (i) we measured the acorn production of Quercus mongolica, an overwhelmingly dominant species in South Korea, for 3 years (2017-2019), (ii) evaluated the spatial-temporal variation of acorn production, and (iii) analyzed the effects of oak- and site-related variables on the acorn production.

Results: The annual acorn production of Q. mongolica increased 36 times from $1.2 \mathrm{~g} \mathrm{~m}^{-2}$ in 2017 to $43.2 \mathrm{~g} \mathrm{~m}^{-2}$ in 2018 , and decreased to $16.7 \mathrm{~g} \mathrm{~m}^{-2}$ in 2019, resulting in an annual coefficient of variation of 104\%. The coefficient of spatial variation was high and reached a maximum of $142 \%$, and the tree size was the greatest influencing factor. That is, with an increase in tree size, acorn production increased significantly $(2018 F=16.3, p<0.001 ; 2019 F=8.2, p<0.01)$.

Elevation and slope also significantly affected the production in 2019. However, since elevation and tree size showed a positive correlation $(r=0.517, p<0.001)$, the increase in acorn production with increasing elevation was possibly due to the effect of tree size. The acorn production of Odaesan for 3 years was 2.2 times greater than that of Seoraksan. This was presumed that there are more distribution of thick oak trees and more favorable site conditions such as deep soil A-layer depth, high organic matter, and slower slopes.

Conclusion: As reported for other species of the genus Quercus, the acorn production of Q. mongolica showed large spatial and annual variations. The temporal variability was presumed to be a weather-influenced masting, while the spatial variability was mainly caused by oak tree size.
\end{abstract}

Keywords: Masting, Quercus forest, Spatial heterogeneity, Synchronization

\section{Background}

The genus Quercus is an evolutionarily successful taxa with more than 500 species around the world (McShea and Healy 2002). Most species in the Genus Quercus have high resistance and resilience to disturbances, thereby making them highly adaptable against such disturbances. Additionally, they have been considered as a member of the late successional forests due to their long life span although they are not late-successional species themselves (Abrams 1992; McShea and Healy 2002; Choung et al.

\footnotetext{
* Correspondence: yschoung@kangwon.ac.kr

${ }^{1}$ Department of Biological Sciences, Kangwon National University, Chuncheon 24341, South Korea

Full list of author information is available at the end of the article
}

2020). These characteristics contribute to the successful formation of large oak forests in the world.

The acorns produced by oak trees are not only food for humans, but are also important food sources for wild animals. For that reason, the annual production of acorns has been of significant concern. However, the production is highly variable and shows masting phenomenon in a specific year (e.g., Silvertown 1980; Sork and Bramble 1993; Kelly 1994; Koenig et al. 1994; Koenig and Knops 2002; Abrahamson and Layne 2003; Liebhold et al. 2004; Bogdziewicz et al. 2018). Here, masting is defined as the phenomenon in which a plant population intermittently reproduces on a large scale (Kelly 1994). Some plant species, particularly well-known in the bamboo family, have evolved

(c) The Author(s). 2020 Open Access This article is licensed under a Creative Commons Attribution 4.0 International License, which permits use, sharing, adaptation, distribution and reproduction in any medium or format, as long as you give appropriate credit to the original author(s) and the source, provide a link to the Creative Commons licence, and indicate if changes were made. The images or other third party material in this article are included in the article's Creative Commons licence, unless indicated otherwise in a credit line to the material. If material is not included in the article's Creative Commons licence and your intended use is not permitted by statutory regulation or exceeds the permitted use, you will need to obtain permission directly from the copyright holder. To view a copy of this licence, visit http://creativecommons.org/licenses/by/4.0/. 
to have a reproductive strategy that achieves masting through synchronization, where many individuals simultaneously produce large numbers of seeds in large geographical areas (Janzen 1971; Smith et al. 1990; Kelly and Sullivan 1997; Koenig and Knops 2002).

Populations or individuals of the masting species have different phenomena of masting which result in variations in the annual acorn production (e.g., Goodrum et al. 1971; Sork and Bramble 1993; Cecich and Sullivan 1999; Healy et al. 1999; Greenberg 2000; Koenig and Knops 2002). Masting is generally influenced by several factors, of which the genetic effect is the most prominent followed by climate and site environment. In particular, climatic variables have been reported as one of the factors that cause synchronization by having similar effects on oak individuals that are geographically close and have similar site conditions (Koenig and Knops 2002; Liebhold et al. 2004). During the flowering period in spring, the effects of temperature (Quercus suber, Quercus petraea, Quercus robur) (Ramírez-Valiente et al. 2009; Caignard et al. 2017) and precipitation (Quercus ilex) have been reported (e.g., Sánchez-humanes and Espelta 2011). Koenig and Knops (2002) assumed that during the spring, warm temperature and dry condition increase the acorn production of white oak, a 1-year species whose acorns mature within a year.

Much attention has been paid to temporal variation of acorn production. In contrast, spatial variations caused by differences in stand conditions remained mostly unexplored. Even in regions with the same climatic conditions, the age and structure of oak trees are different depending upon forest development or disturbance history. Moreover, the influence of site variables, such as elevation is also large. Therefore, spatial variation also needs to be studied.

There are 20 taxa (including variety) that belong to the genus Quercus in the Korean Peninsula (NIBR 2020). Among them, six deciduous oaks are common and abundant in South Korea (Q. mongolica Fisch. ex Ledeb, Q. serrata Murray, Q. aliena Blume, Q. dentata Thunb, Q. variabilis Blume, and $Q$. acutissima Carruth). These six species occupy $48.1 \%$ of broad-leaved forests (KFS 2019a). Among the abovementioned 6 oak species, the first four are 1-year species, and the last two are 2-year species (Lee 2003). In particular, Q. mongolica, a 1-year species, is the most predominant across the country (NGII 2016; Choung et al. 2020). Most forests in South Korea had been restored since 1970s after repeated and long disturbances, resulting in area of young forest that is overwhelmingly large. The relatively mature oak forests could be found in well-preserved areas, such as the national parks. Since oak species are succeeding $P$. densiflora trees in the succession process, the area of oak forest can increase significantly in the near future (Choung et al. 2020).

Surprisingly, the research on acorn production was conducted only in Jirisan National Park (SRC 2009; NIBR
2014; SRTI 2014). Among the Korean native species, studies have been done on $Q$. mongolica var. crispula and $Q$. serrata in Japan (Imada et al. 1990; Shibata et al. 2002). Therefore, we aimed first to examine acorn production in spatially diverse locations of Seoraksan and Odaesan National Parks for 3 years from 2017 to 2019, second to evaluate the temporal and spatial variation of acorn production, and third to analyze oak- and site-related variables that have an effect on the acorn production.

\section{Methods}

\section{Study area: Seoraksan and Odaesan National Parks}

Seoraksan National Park (398.24 $\mathrm{km}^{2}$ in area), designated as a Biosphere Preservation District by UNESCO, is located in the northeastern part of South Korea (Fig. 1). It consists of about 30 peaks, including the highest peak, Daecheongbong $\quad(1708 \mathrm{~m}$ high, N38.119189 E128.465253 ${ }^{\circ}$ (KNPS 2016). The park has a cooltemperate climate with annual temperate $10.1^{\circ} \mathrm{C}$ and annual precipitation of $1210.5 \mathrm{~mm}$ (from Inje meteorological station, KMA 2020). The terrain is mostly rocky and steep. About $80 \%$ of the vegetation comprises oak forests (mainly Q. mongolica-deciduous mixed forests and Q. mongolica-Pinus densiflora mixed forests) (KNPRI 2016). In addition, some subalpine forests are distributed at high altitudes, while pine forests in the low and rocky areas.

Odaesan National Park $\left(326.35 \mathrm{~km}^{2}\right.$ in area) is located about $40.5 \mathrm{~km}$ south of Seoraksan (Fig. 1). The highest peak is Birobong $(1536 \mathrm{~m}$ high, N37.760791 E128.577475 $)$ (KNPS 2016). Odaesan National park also has cool-temperate climate with annual temperate $6.6{ }^{\circ} \mathrm{C}$ and annual precipitation of $1898.0 \mathrm{~mm}(18 \mathrm{~km}$ away from Daegwallyeong meteorological station) (KMA 2020). Majority of the terrains in Odaesan are relatively smooth, and slopes are gradual, in contrast to Seoraksan. About $94 \%$ of the current vegetation is oak-dominated forests. More than half of the forest is occupied by $Q$. mongolica, and the rest are broadleaved-mixed forests containing Q. mongolica, Tilia amurensis, Carpinus cordata, etc. (Choung et al. 2004). Abies holophylla-broadleaved-mixed forest developed in some areas, whereas subalpine forests of $A$. nephrolepis and Taxus cuspidata can also be found (KNPRI 2016).

\section{Establishment of collection trap and the measurement of acorn production}

The survey was conducted in six regions, three in each park (Fig. 1, Suppl. 1). Those regions are Hangyeryeong, Jeombongsan, and Misiryeong in Seoraksan, while Duroryeong, Seodaesa, and Jingogae in the Woljeongsa district of Odaesan. In 2017, 6 stands were selected in each region (a total of 36 stands), and 4 more were added in 2019, resulting in a total of 40 stands. The location of 


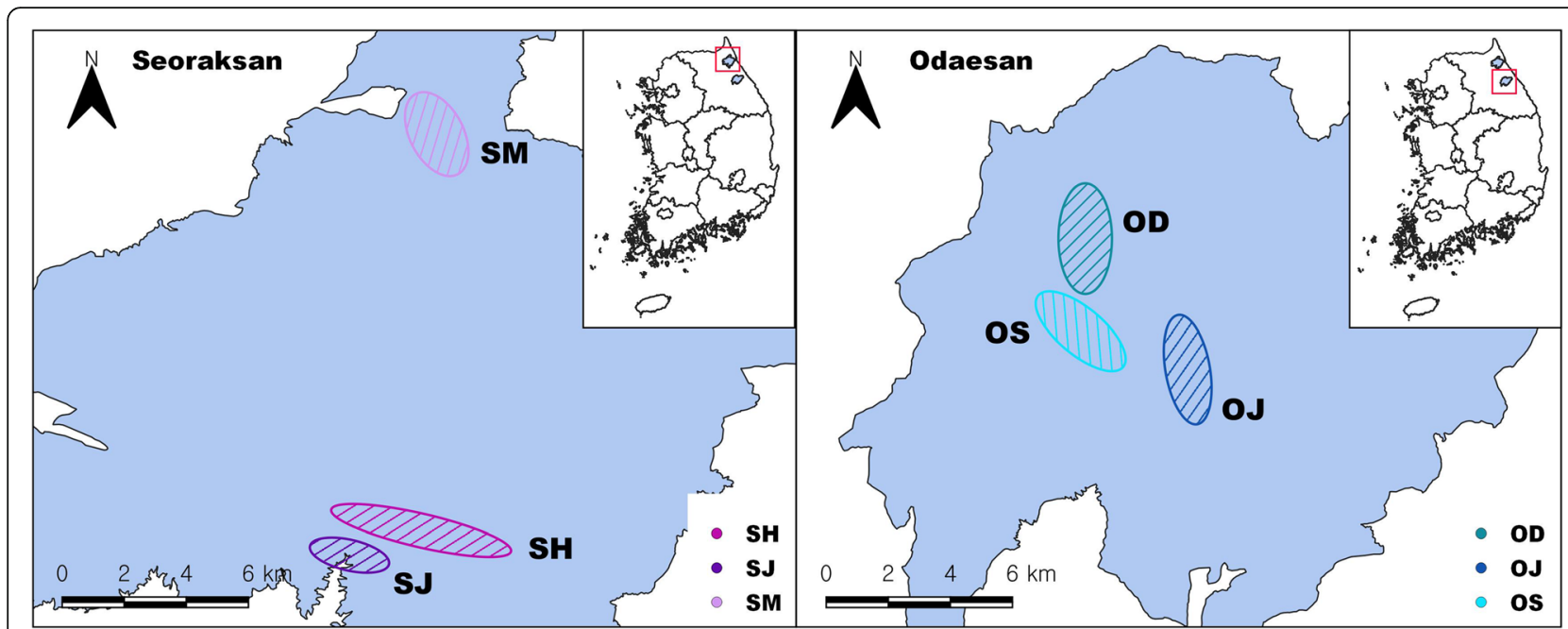

Fig. 1 The studied six regions in Seoraksan (left) and Odaesan National Parks (right). SH, SJ, and SM: Hangyeryeong, Jeombongsan, and Misiryeong in Seoraksan, respectively. OD, OS, and OJ: Duroryeong, Seodaesa, and Jingogae, respectively. Thirty-six stands (108 traps) in six regions were selected in 2017 and 2018, while 40 stands (120 traps) in 2019. For GPS and topographic information of the investigated stands in detail, refer to Suppl. 1

the stands was determined based on the size of oak tree and elevation of the site.

In both parks, the survey stands were closed forests with more than $90 \%$ coverage of the canopy stratum. Thirteen canopy tree species such as $P$. densiflora, Betula davurica, Tilia amurensis, and Acer pseudosieboldianum, including the most dominant Q. mongolica, occurred in Seoraksan. Whereas in Odaesan, 17 species presented, including all species that occurred in Seoraksan.

For each stand, three collection traps were installed within a $20 \times 20 \mathrm{~m}^{2}$ area (total 108 traps in 2017 and 2018, and 120 traps in 2019). Three healthy oak trees of similar thickness were selected as target trees for each stand. A rectangular-shaped trap $\left(1 \times 1 \mathrm{~m}^{2}\right)$, made of polyester mesh, was placed under a target oak tree with its bottom $50 \mathrm{~cm}$ above the ground to prevent feeding damage by animals such as rodents. It was tied to surrounding trees.

In order to collect the annual production of acorns, the traps were emptied every spring. From each trap, the acorns were collected twice every year at the end of September and October and summed. The average value of the three traps was used as annual acorn production (hereafter "AP") for each stand. In case a trap was damaged by wind, animal, or human interference, it was excluded from the calculation.

AP is the dry weight of acorns produced per unit stand, including cap. The weight was measured after drying the acorns for $24 \mathrm{~h}$ in a drying oven at $80^{\circ} \mathrm{C}$. Unit weight and number of acorns for 2017 and 2019 have been presented in Suppl. 2. Almost all of the acorns collected were of $Q$. mongolica, and only one or two acorns of Q. serrata were found in one trap in 2018 and two traps in 2019.

\section{Vegetation and site survey}

For each stand, the coverage by oak trees was measured in the canopy stratum ( $\geq 8 \mathrm{~m}$ high). The diameter at breast height $(\mathrm{DBH} \geq 6 \mathrm{~cm}$ ) of all the tree species including the oaks was measured in a temporary plot of $10 \times$ $10 \mathrm{~m}^{2}$. The stems which branched below $1.3 \mathrm{~m}$ high were counted as separate stems. Based on these measurements, oak-related variables such as density, coverage, DBHs of trap oak and stand oak, and oak basal area were calculated. Here, "trap oak" indicates a target oak tree above each trap, while "stand oak" indicates all oaks included in the temporary plot.

Among the site variables, elevation, slope, and aspect were measured, and topography was evaluated qualitatively as one of the following: valley, slope (upper, middle, or lower), and mountain top (including ridge). In addition, the depth of soil and A-horizon was measured at three points in each stand. Organic matter and moisture content were measured in October 2019. Three soil samples were collected using a soil auger $(10 \mathrm{~cm}$ core diameter and $10 \mathrm{~cm}$ deep) and pooled as one sample for each stand. After oven drying at $105^{\circ} \mathrm{C}$ for $4 \mathrm{~h}$, the moisture content of the soil was calculated from the difference between the fresh weight and dry weight. To measure the organic matter content in the soil, the room-temperature dried soil was first filtered through a $5 \mathrm{~mm}$ sieve to remove organic debris. The sample was then dried in a drying oven at $105^{\circ} \mathrm{C}$ for $24 \mathrm{~h}$ and combusted in a furnace at $600^{\circ} \mathrm{C}$ for $4 \mathrm{~h}$, and then, the lost weight was calculated as the organic matter.

\section{Data analysis}

The oak-related variables, such as density, coverage, DBHs of trap oak and stand oak, and oak basal area, 
were used to analyze the relationship of these variables with AP. The oak density was the only one to exhibit normal distribution in the Kolmogorov-Smirnov test, whereas the remaining variables including the AP did not show such distribution. Therefore, the variables were $\log _{10}$-transformed to ensure normality. On the other hand, all the site variables except organic matter content displayed normal distribution in the KolmogorovSmirnov test, and therefore, the organic content was $\log _{10}$-transformed.

Regression analysis was performed to examine the relationship of AP with the oak-related and site variables. Pearson correlation between the variables was also evaluated. SPSS (ver. 24, SPSS 2017) was used for all analyses.

\section{Results}

\section{Annual and spatial variability in acorn production}

The average stand AP was very low in $2017,1.2 \mathrm{~g} \mathrm{~m}^{-2}$, then increased 36.0 times to $43.2 \mathrm{~g} \mathrm{~m}^{-2}$ in 2018 (Fig. 2, Suppl. 2), and again decreased in 2019, $16.7 \mathrm{~g} \mathrm{~m}^{-2}$ which was $38.7 \%$ of the AP in 2018. The APs of six regions fluctuated significantly over the 3 years. Average 93.0\% of the annual acorns were produced by September, and the remaining $7.0 \%$ by October (average of $94.2 \%$ in 2018 and $91.8 \%$ in 2019). The values presented here are the total dry weight including the cap weight. Of these, the cap was $34.9 \%$ of the total weight.

In Seoraksan, the AP increased approximately by 13.7 times from $1.7 \mathrm{~g} \mathrm{~m}^{-2}$ in 2017 to $23.4 \mathrm{~g} \mathrm{~m}^{-2}$ in 2018 . However, it decreased in 2019 to $12.4 \mathrm{~g}$, almost half of that in 2018. On the other hand, the AP of Odaesan was $0.7 \mathrm{~g} \mathrm{~m}^{-2}$ in 2017 and increased by 87.4 times to $62.9 \mathrm{~g}$ $\mathrm{m}^{-2}$ in 2018. However, it decreased in 2019 to $20.6 \mathrm{~g}$ $\mathrm{m}^{-2}$, which is 0.39 times less than that in 2018 (Fig. 2a). It can be observed that in 2018, the AP was significantly higher in Odaesan than Seoraksan $(t=-2.4 p<0.05)$, but in 2017 and 2019, the difference between the APs of the two parks were not significant.

AP for five regions except Hangyeryeong in Seoraksan showed the same trend in their overall pattern. Hangyeryeong, on the other hand, had the lowest AP in 2018, which increased slightly in 2019. Especially in 2018, the APs in Seodaesa and Duroryeong of Odaesan were much higher compared to other regions. Seodaesa had the highest AP, which was 11.3 times higher than Hangyeryeong. In 2019, $72.2 \%$ of the 36 stands had a reduced AP compared to those of 2018 (Fig. 3). However, in some stands, where production was very low, the AP rather increased in 2019. This trend was similar in both parks, but the increase was more in Seoraksan, where the production was lower.

When calculating the annual variation of the AP in 3 years, the coefficient of variation (CV) was $104.2 \%$ (Table 1). The CVs for Seoraksan and Odaesan were $86.7 \%$ and

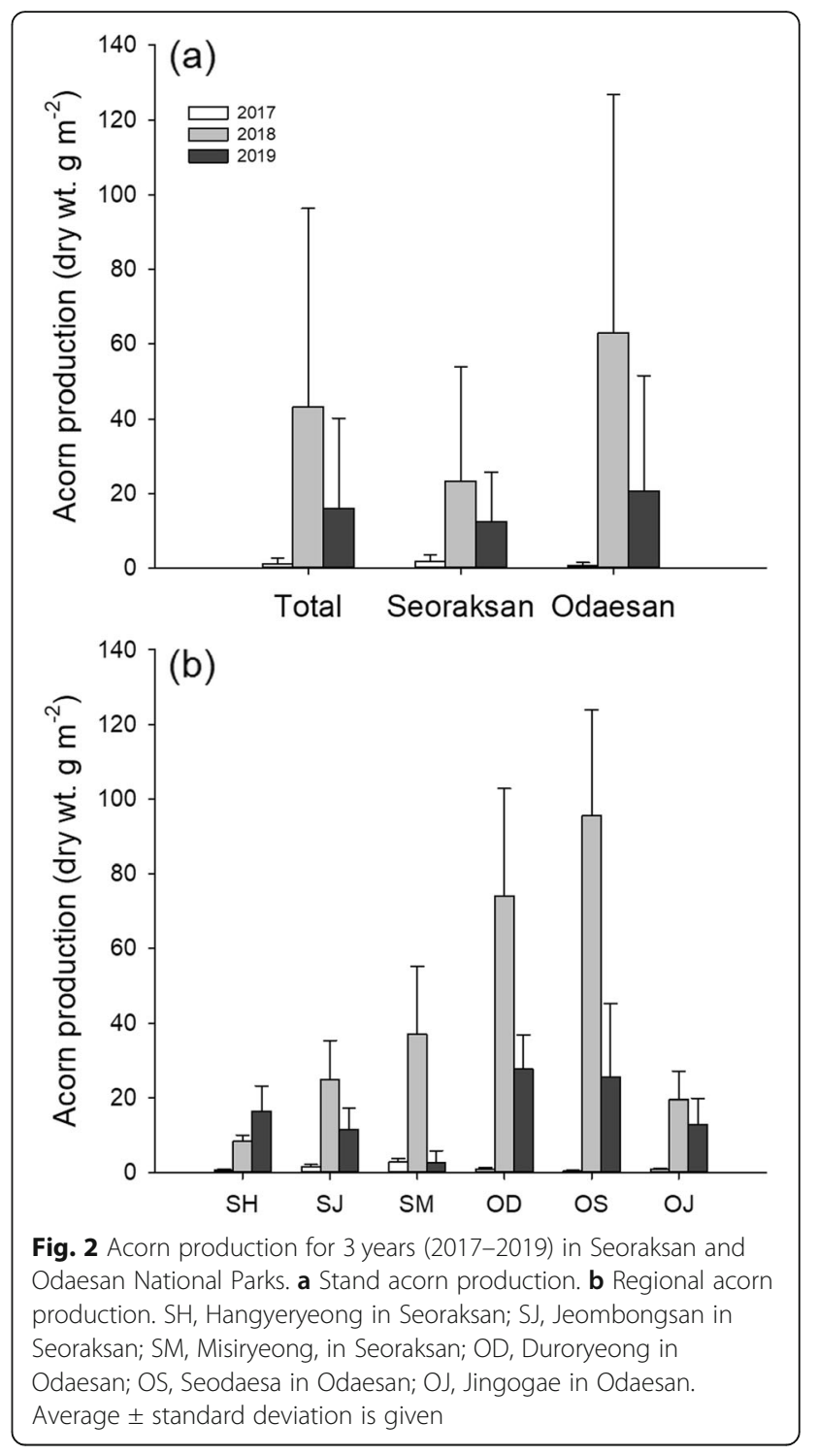

$113.2 \%$, respectively, a higher value for Odaesan. Meanwhile, the $\mathrm{CV}$ of spatial variation between regions within the same year was very large, ranging from 121 to $142 \%$ over the 3 years (2017-2019). In both 2018 and 2019, the difference between the lowest and highest values for each stand was large by more than two digits (Table 1 ).

\section{Distribution of oak trees in the stands and site characteristics}

The surveyed forests were oak-dominated forests, so the coverage of oak trees reached $79.5 \%$. The oak tree density accounted for $46.4 \%$ of the total tree density (Table 2). The average DBH of stand oak was $26.5 \mathrm{~cm}$, while that of the trap oak was $33.7 \mathrm{~cm}$. The coverage of oak was higher in Odaesan, but the density was higher in Seoraksan. This is because there were more thin oak trees in Seoraksan and more thick oak trees in Odaesan (Fig. 4). 


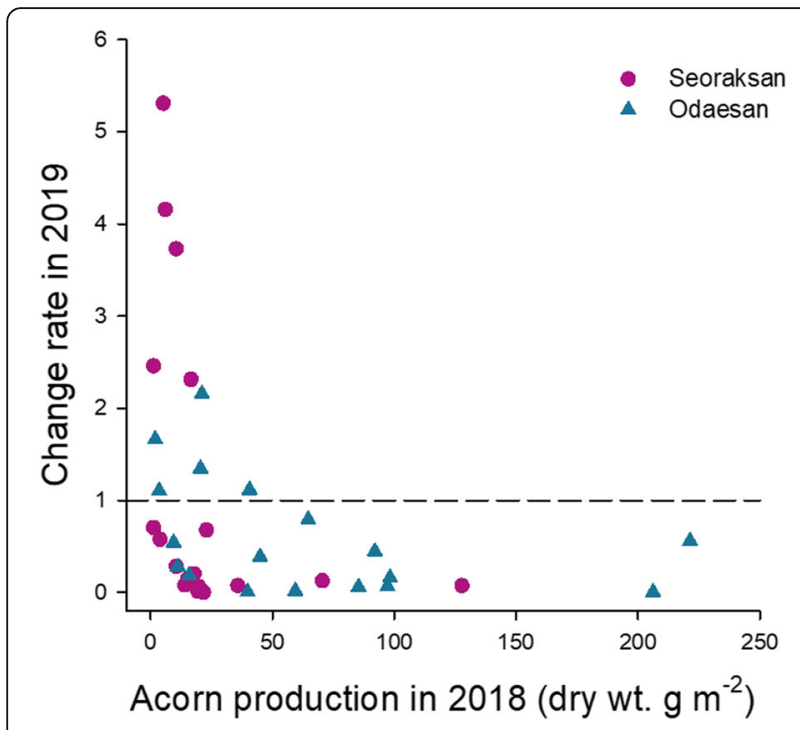

Fig. 3 The rate of stand acorn production between 2018 and 2019 $(N=36)$. Dotted lines indicate that the 2 years of production are the same

The elevation range of the survey stand was broad, from 646 to $1314 \mathrm{~m}$ (Table 3). The average slope was $29.3^{\circ}$, but the deviation was large due to the wide slope range. The slopes of Seoraksan was steeper than Odaesan (Table 3). The soil depth was deeper in Seoraksan, but the soil A-layer depth, organic matter, and moisture content were higher in Odaesan.

\section{Effects of oak- and site-related variables on acorn production}

The effects of oak- and site-related variables on AP were evaluated through regression analysis. This analysis was not done for 2017 because it was considered that other factors had an influence on AP. In 2018, the AP tended to increase significantly as the size of the stand oak and trap oak increased, but decreased significantly with increasing oak density (Table 4, Fig. 5). The AP in 2019 also increased significantly with oak size and basal area (Table 4, Fig. 5).

$\mathrm{DBH}$ of the stand oak showed higher statistics ( $F$ value) than that of the trap oak, and therefore, it turns out to be a better variable. In 2019, the AP tended to increase significantly as the elevation increased and slope decreased (Table 5, Fig. 6). In 2018 also, the AP tended to increase with increase in elevation, but the increase was not so significant. Moreover, soil factors such as soil depth, A-horizon depth, organic matter, and moisture content did not show any significant relationship with AP.

Correlation analysis was performed between all the variables (Table 6). The elevation and slope showed a strong negative relationship. Elevation also had a significant negative correlation with oak density, and a significant positive correlation with $\mathrm{DBH}$ s of both the stand and trap oaks. It meant that the higher the elevation, the less dense and thicker the trees are.

\section{Discussion}

\section{Annual variability and masting in acorn production}

During the 3-year study period, the $\mathrm{CV}$ for the annual AP of Q. mongolica was $104.2 \%$, showing a large variability. Temporal variation has already been identified for $Q$. mongolica as reported for other oak species (e.g., Q. prinus, Q. alba, Q. stellata, Q. lyrata, Q. virginiana, Q. velutina, Q. mongolica var. crispula) (Goodrum et al. 1971; Imada et al. 1990; Sork and Bramble 1993; Kelly 1994; Koenig and Knops 2002). Koenig and Knops (2002) studied five oak trees in California for 19 years, and found that Q. lobata and Q. douglasii, the deciduous tree and 1-year species, showed CV of $93.4 \%$ and $108.8 \%$, respectively. Of these species, some individuals did not produce even a single acorn in 19 years, while some produced a large number of acorns consistently, resulting in extreme variation (Koenig et al. 1994).

In Jirisan where the AP was measured for 6 years (2008 2013), the AP in 2009 was the highest, $94.6 \mathrm{~g} \mathrm{~m}^{-2}$, and the lowest at $3.3 \mathrm{~g} \mathrm{~m}^{-2}$ in 2012 (SRC 2009; NIBR 2014; SRTI 2014). The 6-year average was $26.4 \mathrm{~g} \mathrm{~m}^{-2}$, more than $20.4 \mathrm{~g} \mathrm{~m}^{-2}$ of the present study. In Jirisan, the CV of annual production was $129.0 \%$, which was higher than that of this study. However, in the study of Jirisan, it was not described what the oak species were, and it was only referred to as "oak forests". Considering that the area of Q. mongolica forests (43\%) is the largest in Jirisan, followed by Q. serrata forests (14\%) and Q.

Table 1 Annual and spatial variability in stand acorn production in Seoraksan and Odaesan National parks

\begin{tabular}{|c|c|c|c|c|c|c|c|c|c|}
\hline \multirow[t]{2}{*}{ Year } & \multicolumn{3}{|l|}{ Total } & \multicolumn{3}{|l|}{ Seoraksan } & \multicolumn{3}{|l|}{ Odaesan } \\
\hline & $\begin{array}{l}\text { Min (dry wt. g } \\
m^{-2} \text { ) }\end{array}$ & $\begin{array}{l}\operatorname{Max}(\text { dry wt. g } \\
\mathrm{m}^{-2} \text { ) }\end{array}$ & $\begin{array}{l}\mathrm{CV} \\
\text { (\%) }\end{array}$ & $\begin{array}{l}\text { Min (dry wt. g } \\
m^{-2} \text { ) }\end{array}$ & $\begin{array}{l}\text { Max (dry wt. g } \\
\mathrm{m}^{-2} \text { ) }\end{array}$ & $\begin{array}{l}\mathrm{CV} \\
\text { (\%) }\end{array}$ & $\begin{array}{l}\text { Min (dry wt. g } \\
\mathrm{m}^{-2} \text { ) }\end{array}$ & $\begin{array}{l}\text { Max (dry wt. g } \\
\mathrm{m}^{-2} \text { ) }\end{array}$ & $\begin{array}{l}\text { CV } \\
(\%)\end{array}$ \\
\hline 2017 & 0.0 & 7.2 & 121.2 & 0.0 & 7.2 & 107.5 & 0.0 & 36.0 & 106.3 \\
\hline 2018 & 1.2 & 221.3 & 123.4 & 1.2 & 206.2 & 130.6 & 2.0 & 221.3 & 101.5 \\
\hline 2019 & 0.0 & 123.2 & 142.2 & 0.0 & 52.4 & 129.8 & 0.2 & 123.2 & 140.3 \\
\hline Annual & 1.2 & 43.2 & 104.2 & 1.7 & 23.4 & 86.7 & 0.7 & 62.9 & 113.2 \\
\hline
\end{tabular}


Table 2 Oak tree distribution in Seoraksan and Odaesan National Parks

\begin{tabular}{llll}
\hline Variable & Total $(\boldsymbol{N}=\mathbf{4 0})$ & Seoraksan $(\boldsymbol{N}=\mathbf{1 9})$ & Odaesan $(\boldsymbol{N}=\mathbf{2 1})$ \\
\hline Oak coverage at canopy stratum (\%) & $79.5 \pm 18.9$ & $76.6 \pm 19.7$ & $82.1 \pm 18.3$ \\
No. of oak stems $\left(\mathrm{No} . \mathrm{ha}^{-1}\right)$ & $760.0 \pm 511.3$ & $842.1 \pm 587.2$ & $685.7 \pm 432.8$ \\
No. of total stems $\left(\mathrm{No} . \mathrm{ha}^{-1}\right)$ & $1637.5 \pm 597.3$ & $1457.9 \pm 464.7$ & $1800.0 \pm 665.6$ \\
Stand oak DBH $(\mathrm{cm})$ & $26.5 \pm 9.5$ & $24.7 \pm 9.6$ & $28.1 \pm 9.2$ \\
Trap oak DBH $(\mathrm{cm})$ & $33.7 \pm 15.6$ & $29.3 \pm 11.1$ & $37.7 \pm 18.1$ \\
Oak basal area $\left(\mathrm{m}^{2} \mathrm{ha}^{-1}\right)$ & $36.9 \pm 23.7$ & $34.0 \pm 18.4$ & $39.5 \pm 27.8$ \\
\hline
\end{tabular}

Average \pm standard deviation is given. Stems $(\mathrm{DBH} \geq 6 \mathrm{~cm})$ were measured

variabilis forests (11\%) (KNPRI 2018), it is likely that the acorns of these three species were mixed. If so, since $Q$. variabilis is a 2-year species, the CV might be large depending on the proportion of this species. However, on the other hand, it is more probable that Q. mongolica would dominate, considering that the elevation of the study area is 700 to $1200 \mathrm{~m}$ (SRC 2009, NIBR 2014, SRTI 2014).

Greenberg and Parresol (2002) defined mast year as the year of production higher than the 5-year average production. Applying this to Jirisan study, the average AP for 5 years $(2008-2012)$ was $30.0 \mathrm{~g} \mathrm{~m}^{-2}$. The AP in 2009 was more than three times this value, so it can be regarded as a mast year. If we apply this value to our data, 2018 could be as a mast year. Imada et al. (1990) studied Q. mongolica var. crispula for 20 years. There were two mast years in 10-year cycles, and the rest of the period showed slight fluctuation in biennial cycles. Our study was unable to determine whether the mast year of $Q$. mongolica had periodicity because the study period was only for 3 years. In Jirisan, 2009 was a mast year, but no periodic trend was identified. Through this, we found that Q. mongolica has a mast year, but no "strict masting" with a certain periodicity (Kelly 1994) was observed. Koenig and Knops (2002) analyzed the periodicity of acorn production in the Northern Hemisphere using only data for a study period of at least 15 years or more. In their work, 1-year species $Q$. alba had a cycle of 2.0-2.4 years, and 2-year species $Q$. velutina had a cycle of 4.6-6.3 years. Although the tendency of bimodality between masting and nonmasting in 1-year species was shown, the two modes could not be distinguished clearly. In the study of Q. mongolica production in Jirisan, it was difficult to find the trend of bimodality.

In 2017, it was estimated that oak trees were damaged by diseases or insect pests, even though no reports of outbreaks in the oak forest were found. Most of the acorns collected at that time were unusually small and deformed with holes. Moreover, 54\% of the total 108 traps did not contain a single acorn. Studies have shown that in the year of low AP, the number of produced acorns was low, and the maturity rate was low as well

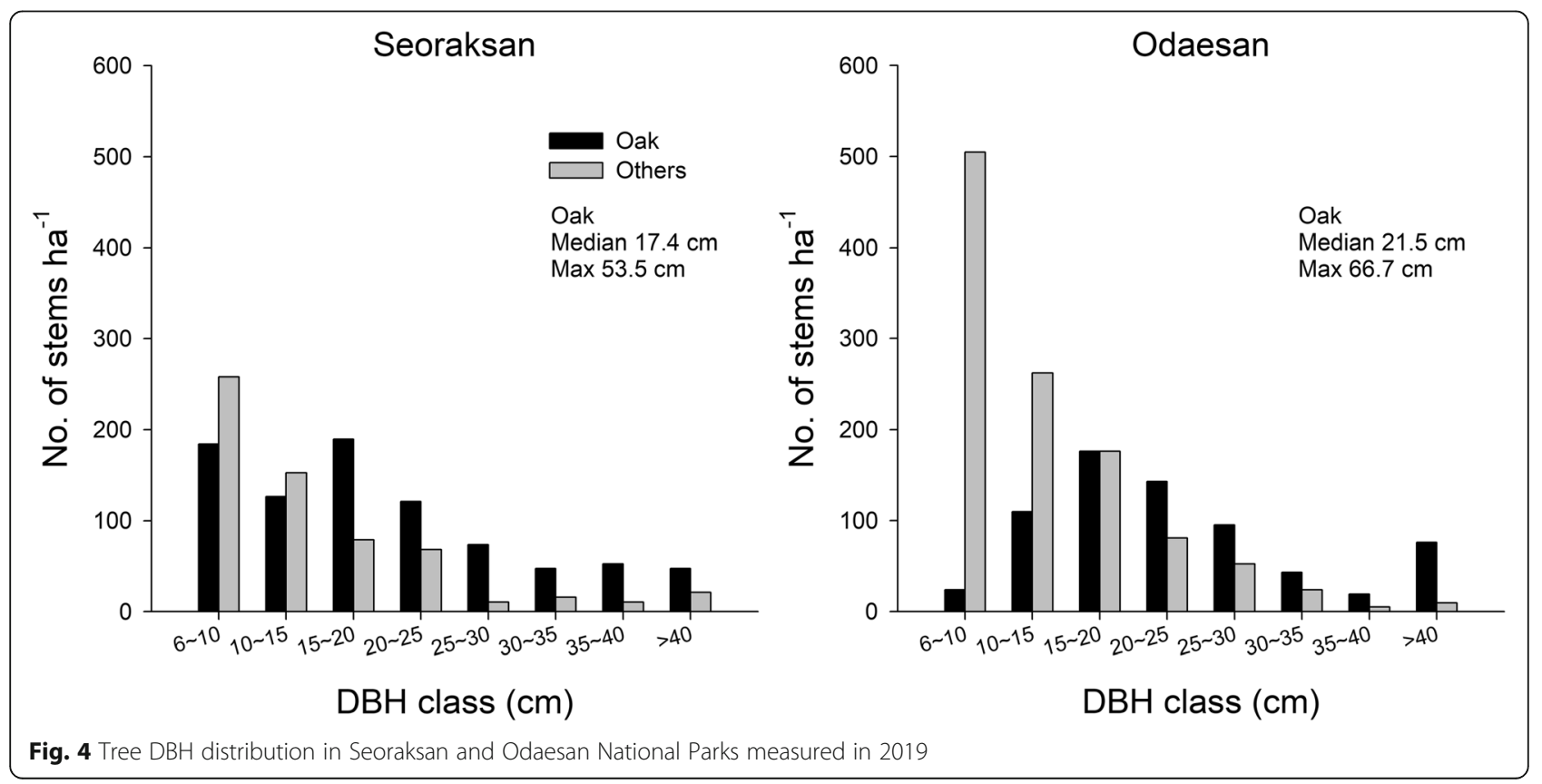


Table 3 Site characteristics of Seoraksan and Odaesan National Parks

\begin{tabular}{llll}
\hline Variable & Total $(\boldsymbol{N}=\mathbf{4 0})$ & Seoraksan $(\boldsymbol{N}=\mathbf{1 9})$ & Odaesan $(\boldsymbol{N}=\mathbf{2 1})$ \\
\hline Elevation $(\mathrm{m})$ & $969.5 \pm 178.1$ & $864.7 \pm 146.8$ & $1064.3 \pm 150.2$ \\
Slope $\left(^{\circ}\right)$ & $29.3 \pm 8.2$ & $31.3 \pm 7.1$ & $27.4 \pm 8.9$ \\
Soil depth $(\mathrm{cm})$ & $35.3 \pm 11.6$ & $39.1 \pm 13.0$ & $31.7 \pm 9.0$ \\
Soil A-layer depth $(\mathrm{cm})$ & $2.6 \pm 2.0$ & $1.8 \pm 1.4$ & $3.4 \pm 2.1$ \\
Soil organic matter (\%) & $23.6 \pm 8.5$ & $20.6 \pm 5.2$ & $26.3 \pm 10.0$ \\
Soil water content $(\%)$ & $33.2 \pm 8.8$ & $30.7 \pm 10.5$ & $35.5 \pm 6.3$ \\
\hline
\end{tabular}

Average \pm standard deviation is given

(Goodrum et al. 1971; Healy et al. 1999). To determine whether such poor production for the year was confined to the surveyed area or it was also a widespread phenomenon in other regions too, we consulted two national park offices and acorn collectors in Inje county and Chuncheon city, tens of kilometers away from two parks. We found there were very low APs in a fairly large area in 2017. As another evidence, the amount of acorns KFS purchased in 5 years (2014-2018) was investigated (KFS 2015, 2016, 2017, 2018, 2019b). Common in five provinces (Gangwon, Chungbuk, Chungnam, Gyeongbuk, and Gyeongnam), it was found to be the lowest in 2017 and increased by $2-5$ times in 2018. It appears to be geographical synchronization over a spatial range of several hundred kilometers or more (Koenig and Knops 2002).

In both the national parks, the production of each stand increased greatly in 2018, showing a masting phenomenon, and then $72 \%$ of the stands decreased simultaneously in 2019. It is presumed to be due to the synchronization of $Q$. mongolica. The six regions in Jirisan also displayed masting in 2009. Koenig and Knops (2002) reported synchronization for the population of five species, and Koenig and Knops (2002, 2013) estimated that synchronization in close geographic regions is caused by certain climatic factors, such as warm temperatures and somewhat dry conditions in spring flowering period. This synchronization has been said to be responsible for increasing the productivity of a number of species belonging to the white oak subgenus, particularly in the 1-year species.

During the flowering period in 2018 (April to May), the temperature of Seoraksan was similar to previous years but higher in Odaesan. Additionally, precipitation in the two parks was 1.9 and 1.6 times higher than the previous years, respectively. In Korea, spring drought is a limiting factor for plant growth. Therefore, an increase in precipitation could promote plant growth. In 2019, both the national parks had lower temperatures than the previous years in April and higher in May. Precipitation was lower in the two parks than in the previous year. In particular, the drought in May seemed to have caused the decline in production.

\section{Spatial variability in acorn production: oak- and site- related variables}

The CV, a measure of spatial variability among the stands, was very large for 3 years, ranging from 121 to $142 \%$. It was greater than the annual variability. In the same year, the difference in stand AP between the minimum and maximum values showed a two-digit difference. The spatial variability in the same year is mainly affected by both oak- or site-related variables, among which, the size of the oak tree is the most influential. The thicker the oak, the greater was the production. This was the same for both 2018 and 2019. Even though a trap was placed under an individual oak tree, both the trap DBH and the stand DBH had a significant effect on the AP. The $F$ value of the stand DBH was larger, resulting in better predictor for AP. This indicated that unit area production is affected not only by the oak tree directly above the trap, but also by the surrounding oak trees.

The range of DBH in the current study was 9.3-46.5 $\mathrm{cm}$. It is already known that AP is affected by the size of the tree (Goodrum et al. 1971; Beck 1977; Dey 1995; Healy et al. 1999; Greenberg 2000). Dey (1995) reported

Table 4 Regression analysis of the effects of oak-related variables on the acorn production in Seoraksan and Odaesan National Parks

\begin{tabular}{|c|c|c|c|c|c|c|c|c|}
\hline \multirow[t]{2}{*}{ Variables } & \multicolumn{4}{|l|}{2018} & \multicolumn{4}{|l|}{2019} \\
\hline & $a$ & b & $F$ & $\overline{p \text { value }}$ & $a$ & b & $F$ & $p$ value \\
\hline No. of oak stems & 1.668 & -0.000 & 6.957 & 0.013 & 1.015 & -0.000 & 1.934 & 0.172 \\
\hline Stand oak DBH ${ }^{a}$ & -1.407 & 1.959 & 16.355 & $<0.001$ & -1.782 & 1.840 & 8.284 & 0.007 \\
\hline Trap oak DBH ${ }^{a}$ & -1.171 & 1.677 & 15.663 & $<0.001$ & -1.141 & 1.293 & 4.961 & 0.032 \\
\hline Stand oak $B A^{a}$ & 0.852 & 0.318 & 0.862 & 0.360 & -0.477 & 0.853 & 4.823 & 0.034 \\
\hline
\end{tabular}

$a$ intercept, $b$ regression coefficient, stand $D B H$ average oak DBH in stand, trap DBH average oak DBH by trap, stand BA oak basal area in stand

${ }^{\mathrm{a}} \log _{10}$-transformed, $p<0.05$ in bold 

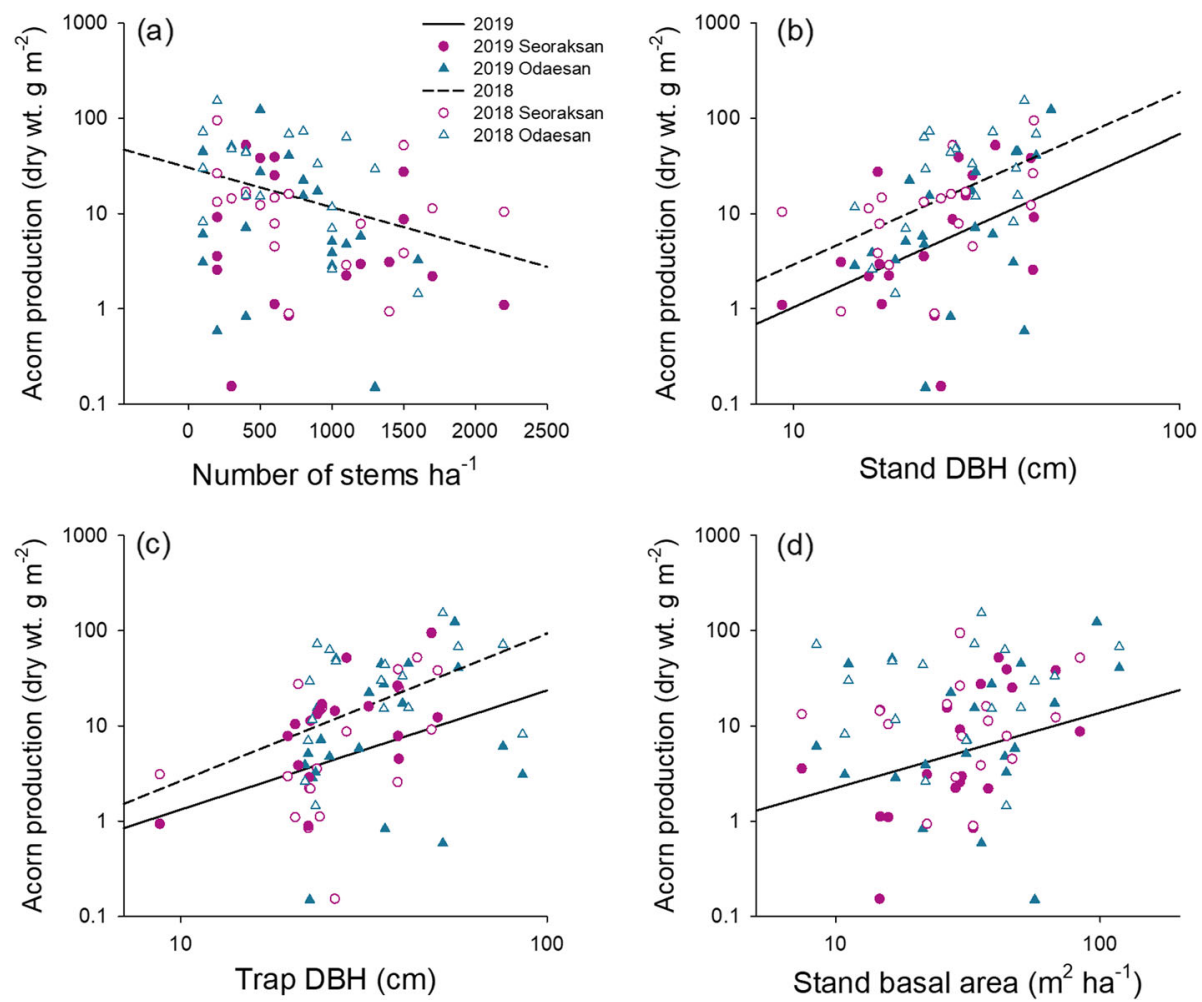

Fig. 5 Regression analysis of acorn production (2018 and 2019) and oak-related variables. a Number of oak stems, b Stand DBH, c Trap DBH, and d Stand basal area. Regression line is shown only when the regression coefficient is significant $(p<0.05)$

that the highest AP was found when the diameter was $41-56 \mathrm{~cm}$ for $Q$. robur, and less when it was smaller or larger than this range. Greenberg and Parresol (2002) found that the APs of Q. robur, Q. alba, and Q. velutina were significantly less in trees with a diameter less than $25 \mathrm{~cm}$ compared to trees with diameter larger than 25 $\mathrm{cm}$. Even though the AP tended to increase with diameter in this study, it was predicted that AP decreases due to slowing of physiological function when oak trees exceed a certain size. In addition, the AP showed a negative correlation with the tree density. This indicated that fewer thick trees contribute to AP rather than many thin trees with low productivity. The density and DBH also showed a significant negative correlation, and it is a natural process that over time the number of trees decrease by thinning and the remaining trees become thicker (Barbour et al. 1999).

Among the site variables, elevation showed a significant relationship with the AP of 2019 , and with the AP of 2018, the relationship was not significant. If the vegetation structure is similar regardless of elevation, the production will decrease with increase in the elevation (Galván et al. 2012; Caignard et al. 2017; Roukos et al. 2017). This is because the higher the elevation, the lower the temperature, the more evapotranspiration, and drier, which are unfavorable conditions for plant growth and

Table 5 Regression analysis of the effect of site variables on the acorn production in Seoraksan and Odaesan National Parks

\begin{tabular}{|c|c|c|c|c|c|c|c|c|}
\hline \multirow[t]{2}{*}{ Variable } & \multicolumn{4}{|l|}{2018} & \multicolumn{4}{|l|}{2019} \\
\hline & $\bar{a}$ & b & $F$ & $\overline{p \text { value }}$ & $\bar{a}$ & b & $F$ & $p$ value \\
\hline Elevation & 0.441 & 0.001 & 3.165 & 0.084 & -1.425 & 0.002 & 18.911 & 0.000 \\
\hline Slope & 1.156 & 0.006 & 0.215 & 0.646 & 1.743 & -0.033 & 6.484 & 0.015 \\
\hline Soil depth & 1.614 & -0.008 & 0.919 & 0.344 & 1.087 & -0.009 & 0.769 & 0.386 \\
\hline Soil A-layer depth & 1.438 & -0.044 & 0.783 & 0.382 & 0.543 & 0.091 & 2.668 & 0.111 \\
\hline Soil $\mathrm{OM}^{\mathrm{a}}$ & 1.859 & -0.396 & 0.328 & 0.571 & 0.057 & 0.538 & 0.438 & 0.512 \\
\hline Soil water content & 1.133 & 0.006 & 0.268 & 0.608 & 0.810 & -0.001 & 0.004 & 0.950 \\
\hline
\end{tabular}

$a$ intercept, $b$ regression coefficient, Soil OM soil organic matter

${ }^{a} \log _{10}$-transformed, $p<0.05$ in bold 


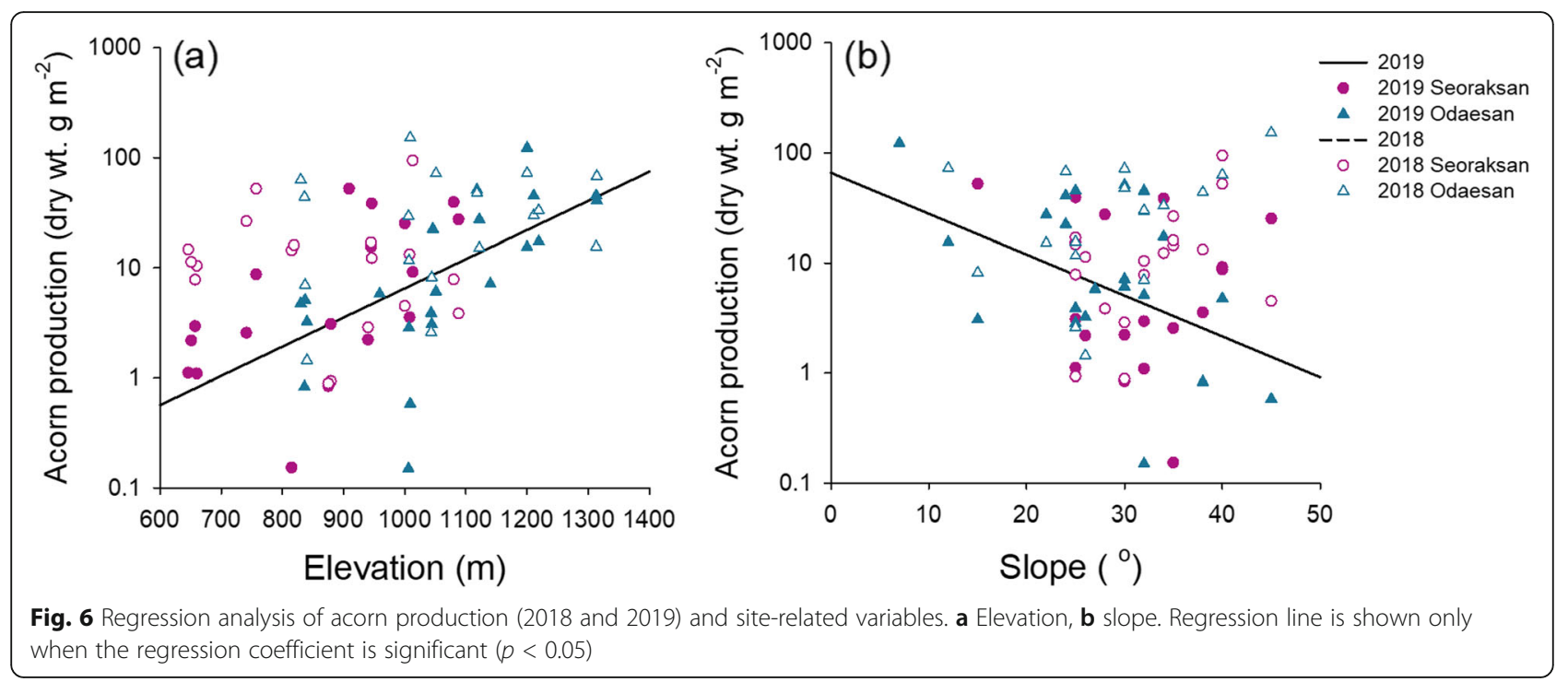

reproduction. Nevertheless, in the present study, elevation-related increase of AP may be because with rise in elevation, the thicker oak trees are more distributed, rather than the direct effect of elevation. In both the parks, the relatively thinner trees are distributed at low elevation due to past disturbances. This was verified by the positive correlation between elevation and tree size.

The slope is likely to have a direct impact on production (Yanagisawa and Fujita 1999; Osman and Barakbah 2006). This may be because the moisture and organic

Table 6 Pearson correlations between oak-related and site-related variables

\begin{tabular}{|c|c|c|c|c|c|c|c|c|c|c|}
\hline & Variable & $\begin{array}{l}\text { No. of } \\
\text { stems }\end{array}$ & $\begin{array}{l}\text { Stand } \\
\mathrm{DBH}^{\mathrm{a}}\end{array}$ & $\begin{array}{l}\text { Trap } \\
\text { DBH }^{\mathrm{a}}\end{array}$ & $\begin{array}{l}\text { Stand } \\
\mathrm{BA}^{\mathrm{a}}\end{array}$ & Elevation & Slope & $\begin{array}{l}\text { Soil } \\
\text { depth }\end{array}$ & $\begin{array}{l}\text { Soil A } \\
\text { depth }\end{array}$ & $\begin{array}{l}\text { Soil water } \\
\text { content }\end{array}$ \\
\hline \multirow{9}{*}{$\begin{array}{l}\text { Pearson } \\
\text { correlation }\end{array}$} & Stand $\mathrm{DBH}^{\mathrm{a}}$ & -0.770 & & & & & & & & \\
\hline & Trap DBH & -0.613 & 0.809 & & & & & & & \\
\hline & Stand $B A^{a}$ & 0.280 & 0.287 & 0.137 & & & & & & \\
\hline & Elevation & -0.415 & 0.517 & 0.409 & 0.189 & & & & & \\
\hline & Slope & -0.006 & 0.002 & -0.067 & -0.074 & -0.316 & & & & \\
\hline & Soil depth & -0.048 & 0.063 & 0.068 & 0.060 & -0.179 & 0.080 & & & \\
\hline & $\begin{array}{l}\text { Soil A-layer } \\
\text { depth }\end{array}$ & -0.017 & 0.013 & 0.123 & -0.016 & 0.212 & 0.012 & -0.023 & & \\
\hline & $\begin{array}{l}\text { Soil water } \\
\text { content }\end{array}$ & -0.255 & 0.110 & 0.185 & -0.119 & 0.225 & $\overline{0} .198$ & -0.018 & 0.247 & \\
\hline & Soil OM & -0.121 & -0.008 & -0.084 & -0.044 & 0.248 & $\begin{array}{l}- \\
0.064\end{array}$ & -0.105 & 0.473 & 0.510 \\
\hline \multirow[t]{9}{*}{$p$ value } & Stand $\mathrm{DBH}^{\mathrm{a}}$ & 0.000 & & & & & & & & \\
\hline & Trap DBH & 0.000 & 0.000 & & & & & & & \\
\hline & Stand $\mathrm{BA}^{\mathrm{a}}$ & 0.080 & 0.073 & 0.401 & & & & & & \\
\hline & Elevation & 0.008 & 0.001 & 0.009 & 0.243 & & & & & \\
\hline & Slope & 0.972 & 0.991 & 0.681 & 0.650 & 0.047 & & & & \\
\hline & Soil depth & 0.768 & 0.700 & 0.675 & 0.714 & 0.269 & 0.625 & & & \\
\hline & $\begin{array}{l}\text { Soil A-layer } \\
\text { depth }\end{array}$ & 0.916 & 0.936 & 0.448 & 0.924 & 0.188 & 0.942 & 0.888 & & \\
\hline & $\begin{array}{l}\text { Soil water } \\
\text { content }\end{array}$ & 0.113 & 0.500 & 0.252 & 0.463 & 0.164 & 0.221 & 0.910 & 0.125 & \\
\hline & Soil $\mathrm{OM}^{a}$ & 0.456 & 0.959 & 0.607 & 0.788 & 0.122 & 0.695 & 0.517 & 0.002 & 0.001 \\
\hline
\end{tabular}


matter content are low and the root development is difficult where the slope is steep (Hairston and Grigal 1991). Among the study regions, Duroryeong and Seodaesa in Odaesan, where production was high, had a gentle slope in spite of high elevation area. By contrast to this, Seoraksan had many steep slopes at low elevation. Overall, it seems that the distribution of thick oak trees rather than the site condition had a decisive influence on the spatial variability. Nonetheless, site conditions such as slope, soil fertility, and moisture conditions have additional effects.

\section{Implications and limitations}

The temporal and spatial variability in production affect significantly on the population of wildlife that feed on acorns. It is because acorns account for about $47 \%$ of wild boar's food source in the fall (Fournier-Chambrillon et al. 1995), and for 50-90\% of Asiatic black bear's food (Schaller et al. 1989). Massei et al. (1996) have shown that the weight and fertility in wild boars, whose main diets are high-energy acorns and olives, depend on the amount consumed. The population dynamics of the American black bear was influenced by the periodicity of masting year (Pelton 1989). Not only the growth and reproduction of large mammals, but those of small mammals also, such as rodents and siskins were affected by AP (Elias et al. 2004; Clotfelter et al. 2007). Yang et al. (2008) found that the size of home range and habitat use characteristics of Asiatic black bear depended on the amount of food, distribution of food, and habitat condition in Jirisan National Park.

The national parks of Seoraksan and Odaesan are considered as potential habitats to restore Asiatic black bear (Ursus thibetanus ussuricus Heude) following the Jirisan National Park, which is successfully pursuing bear restoration project. Seoraksan is the last area where bear was found in South Korea (The Kyunghyang Shinmun 1983), while Odaesan is the area where a trace of an Asiatic black bear was found in 2015 (KNPS 2017). Moreover, two parks are fairly large and geographically adjacent with oak forests providing abundant food sources.

The present study will contribute to deciding whether to implement bear restoration projects in both the parks. This is because the key information on acorn production at both the stand and region level, and temporal-spatial variability have been provided to estimate the carrying capacity of the bear population. In addition, there is also important information necessary for management when the project should be promoted. Our study found that 93\% of the annual acorn production in both the parks was produced at the end of September. Therefore, presampling at this time is useful to predict the available amount of acorn for wildlife during winter, and thus decide further whether the year is good or bad for wildlife.
If it is a bad year, food can be supplemented during the winter. Then, the potential damage to local residents caused by insufficient food can be prevented.

Our study only revealed the acorn production for $Q$. mongolica. Although this species dominates in South Korea including both the parks (Choung et al. 2020), further studies on other oak species such as $Q$. serrata and $Q$. variabilis are also necessary. Different species will have different reproductive characteristics in terms of production and masting. In particular, 2-year species such as $Q$. variabilis and $Q$. acutissima must be studied. Moreover, since it was revealed that the temporal and spatial variation of oak species was very large, longer term study is necessary in more regions in order to accurately understand the reproductive characteristics of the genus Quercus.

\section{Conclusions}

The acorn production of Q. mongolica was measured in six regions of Seoraksan and Odaesan National Parks for 3 years (2017-2019). In 2017, the production was very low due to presumed causes of diseases or insect pests. However, in 2018, the productivity of most stands increased dramatically due to presumably weatherinvolved synchronization, resulting in masting (36 times larger than in 2017). Consequently, the high annual variability including the masting event, which has been known for other species of the genus Quercus, was also revealed for $Q$. mongolica.

The acorn production showed a large spatial variation at the stand, region, and park level, and we found that the spatial variation was greater than the annual variation. It was analyzed that the key variable causing this spatial heterogeneity was the size of oak tree. The effect of elevation was also significant, but this was presumed to be due to the distribution of many thick oak trees at higher elevation rather than a direct effect of the elevation.

In conclusion, we not only examined the acorn production of Q. mongolica, the most dominant broadleaved species in South Korea, but also confirmed the temporal-spatial variability of this species, although it was for only 3 years. We propose that the production of genus Quercus, including species such as $Q$. variabilis and Q. serrata, is studied over a long period, and internal- and external factors as well as trends in production is revealed.

\section{Supplementary Information}

The online version contains supplementary material available at https://doi. org/10.1186/s41610-020-00169-4.

Additional file 1:. Suppl. 1 Topography and geography of the stands in Seoraksan and Odaesan National Parks $(\mathrm{N}=40)$. Suppl. 2 Acorn production 
for three years (2017-2019) in Seoraksan and Odaesan National Parks (N= 40)

\section{Abbreviations}

AP: Acorn production; CV: Coefficient of variation; KFRI: Korea Forest Research Institute; KFS: Korea Forest Service; KMA: Korea Meteorological Administration; KNPRI: Korea National Park Research Institute; KNPS: Korea National Park Service; NGIll: National Geographic Information Institute; NIBR: National Institute of Biological Resource; SRC: Species Restoration Center; SRTI: Species Restoration Technology Institute

\section{Acknowledgements}

We thank Sangyeop Jung and Jaeyeon Lee for their assistance in the field.

\section{Authors' contributions}

JS carried out the field study and performed the analysis and wrote the manuscript. YJ participated in the design of the study and conducted field study. JS and SY conducted field study and reviewed the manuscript. YS conceived the study and reviewed/edited the manuscript. The authors read and approved the final manuscript.

\section{Funding}

This research was supported by Korea National Park Research Institute, funded by the Ministry of Environment in 2017 (NPRI-2017-05). Research in 2018 and 2019 was supported by the Odaesan and Seoraksan National Park Offices.

\section{Availability of data and materials}

We provide key data as a supplementary. Other data are available from the corresponding author upon request.

\section{Ethics approval and consent to participate}

Not applicable.

\section{Consent for publication}

Not applicable.

\section{Competing interests}

The authors declare that they have no competing interests.

\section{Author details}

'Department of Biological Sciences, Kangwon National University,

Chuncheon 24341, South Korea. ${ }^{2}$ Migang Ecology Institute, Anyang 14057 , South Korea.

\section{Received: 25 September 2020 Accepted: 21 October 2020}

\section{Published online: 12 November 2020}

\section{References}

Abrahamson WG, Layne JN. Long-term patterns of acorn production for five oak species in xeric Florida uplands. Ecology. 2003;84(9):2476-92.

Abrams MD. Fire and the development of oak forests. Bioscience. 1992;42(5):34653.

Barbour MG, Burk JH, Pitts WD, Gilliam FS, Schwartz MW. Terrestrial plant ecology. 3rd ed. Menlo Park: Benjamin Cummings Inc; 1999.

Beck DE. Twelve-year acorn yield in southern Appalachian oaks. Asheville: USDA Forest Service Southeastern Forest Experiment Station; 1977.

Bogdziewicz M, Steele MA, Marino S, Crone EE. Correlated seed failure as an environmental veto to synchronize reproduction of masting plants. New Phytol. 2018;219(1):98-108.

Caignard T, Kremer A, Firmat C, Nicolas M, Venner S, Delzon S. Increasing spring temperatures favor oak seed production in temperate areas. Sci Rep-Uk. 2017;7(1):1-8.

Cecich RA, Sullivan NH. Influence of weather at time of pollination on acorn production of Quercus alba and Quercus velutina. Can J For Res. 1999;29(12): $1817-23$.

Choung Y, Kim S, Shin Y. Vegetation. In: KNPS, editor. Survey on the natural resources in Odaesan National Park. Seoul: KNPS; 2004. p. 195-244. (in Korean).
Choung Y, Lee J, Cho S, Noh J. Review on the succession process of Pinus densiflora forests in South Korea: progressive and disturbance-driven succession. J Ecol Environ. 2020;44:16.

Clotfelter ED, Pedersen AB, Cranford JA, Ram N, Snajdr EA, Nolan V, et al. Acorn mast drives long-term dynamics of rodent and songbird populations. Oecologia. 2007;54(3):493-503.

Dey DC. Acorn production in red oak. Sault Ste. Marie: Forest Research Information Paper; 1995.

Elias SP, Witham JW, Hunter ML. Peromyscus leucopus abundance and acorn mast: population fluctuation patterns over 20 years. J Mammal. 2004;85(4):743-7.

Fournier-Chambrillon C, Maillard D, Fournier P. Diet of the wild boar (Sus scrofa L. ) inhabiting the Montpellier garrigue. J Mt Sci-Engl. 1995;3:174-9.

Galván JV, Novo JJJ, Cabrera AG, Ariza D, García-Olmo J, Cerrillo RMN. Population variability based on the morphometry and chemical composition of the acorn in holm oak (Quercus ilex subsp. ballota [Desf.] Samp.). Eur J For Res. 2012;131(4):893-904.

Goodrum PD, Reid VH, Boyd CE. Acorn yields, characteristics, and management criteria of oaks for wildlife. J Wildl Manag. 1971;35(3):520-32.

Greenberg $\mathrm{CH}$. Individual variation in acorn production by five species of southern Appalachian oaks. For Ecol Manage. 2000;132(2-3):199-210.

Greenberg $\mathrm{CH}$, Parresol BR. Dynamics of acorn production by five species of southern Appalachian oaks. In: McShea WJ, Healy WM, editors. Oak forest ecosystems: ecology and management for wildlife. Baltimore: Johns Hopkins University Press; 2002. p. 149-72.

Hairston AB, Grigal DF. Topographic influences on soils and trees within single mapping units on a sandy outwash landscape. For Ecol Manage. 1991;43(12):35-45.

Healy WM, Lewis AM, Boose AM. Variation of red acorn production. For Ecol Manage. 1999;116(1-3):1-11.

Imada M, Nakai T, Nakamura T, Mabuchi T, Takahashi Y. Acorn dispersal in natural stands of Mizunara (Quercus mongolica var. grosseserrata) for twenty years. J Jpn For Soc. 1990;72(5):426-30.

Janzen DH. Seed predation by animals. Annu Rev Ecol Syst. 1971;2(1):465-92.

Kelly D. The evolutionary ecology of mast seeding. Trends Ecol Evol. 1994;9(12): 465-70.

Kelly D, Sullivan JJ. Quantifying the benefits of mast seeding on predator satiation and wind pollination in Chionochloa pallens (Poaceae). Oikos. 1997; 78(1):143-50.

KFS. Annual survey on the production of forest product in 2014. Daejeon: KFS; 2015. (In Korean).

KFS. Annual survey on the production of forest product in 2015. Daejeon: KFS; 2016. (In Korean).

KFS. Annual survey on the production of forest product in 2016. Daejeon: KFS; 2017. (In Korean)

KFS. Annual survey on the production of forest product in 2017. Daejeon: KFS; 2018. (In Korean).

KFS. Annual survey on the production of forest product in 2018. Daejeon: KFS; 2019a. In Korean

KFS. Yearbook of forestry statistics in 2019. Daejeon: KFS; 2019b. In Korean.

KMA. Monthly weather report. Seoul: KMA; 2020. in Korean.

KNPRI. Survey for the restoration of the Asiatic black bear in the northern region of South Korea. Wonju: KNPS; 2016. (In Korean).

KNPRI. Actual vegetation map of Jirisan National Park. Wonju: KNPS; 2018. (In Korean).

KNPS. National parks of Korea. Wonju: KNPS; 2016. (In Korean).

KNPS. The effects of Asiatic black bear population on the ecosystem. Wonju: KNPS; 2017. (In Korean).

Koenig WD, Knops JM. The behavioral ecology of masting in oaks. In: McShea WJ, Healy WM, editors. Oak forest ecosystems: ecology and management for wild life. Baltimore: Johns Hopkins University Press; 2002. p. 129-48.

Koenig WD, Knops JM. Large-scale spatial synchrony and cross-synchrony in acorn production by two California oaks. Ecology. 2013;94(1):83-93.

Koenig WD, Mumme RL, Carmen WJ, Stanback MT. Acorn production by oaks in central coastal California: variation within and among years. Ecology. 1994; 75(1):99-109.

Lee TB. Coloured flora of Korea. Seoul: Hayangmunsa; 2003. (In Korean).

Liebhold A, Sork V, Peltonen M, Koenig W, Bjørnstad ON, Westfall R, et al. Withinpopulation spatial synchrony in mast seeding of north American oaks. Oikos. 2004;104(1):156-64.

Massei G, Genov PV, Staines BW. Diet, food availability and reproduction of wild boar in a Mediterranean coastal area. Acta Theriol. 1996;41:307-20. 
McShea WJ, Healy WM. Oaks and acorns as a foundation for ecosystem management. In: McShea WJ, Healy WM, editors. Oak forest ecosystems: ecology and management for wildlife. Baltimore: Johns Hopkins University Press; 2002. p. 1-9.

NGII. The national atlas of Korea II. Sejong: NGII; 2016.

NIBR. Study on the habitats for the reintroduction of the endangered species. I: Asiatic black bear. Incheon: NIBR; 2014. (In Korean).

NIBR. National species list of Korea. http://kbr.go.kr. Accessed on 25 June 2020.

Osman N, Barakbah SS. Parameters to predict slope stability-soil water and root profiles. Ecol Eng. 2006;28(1):90-5.

Pelton MR. The impacts of oak mast on black bears in the southern Appalachians. In: McGee CE, editor. Proceedings of the workshop: southern Appalachian mast management. Knoxville: University of Tennessee; 1989. p. 7-11.

Ramírez-Valiente JA, Valladares F, Gil L, Aranda I. Population differences in juvenile survival under increasing drought are mediated by seed size in cork oak (Quercus suber L.). For Ecol Manage. 2009;257(8):1676-83.

Roukos CN, Parissi ZM, Kyriazopoulos AP, Abraham EM. Nutritional quality of kermes oak (Quercus coccifera L.) acorns as affected by altitude in a typical Mediterranean area. Arch Anim Breed. 2017;60(2):71-8.

Sánchez-Humanes B, Espelta JM. Increased drought reduces acorn production in Quercus ilex coppices: thinning mitigates this effect but only in the short term. Forestry. 2011;84(1):73-82.

Schaller GB, Qitao T, Johnson KG, Xiaoming W, Heming S, Jinchu H. The feeding ecology of giant pandas and Asiatic black bears in the Tangjiahe reserve, China. In: Gittleman JL, editor. Carnivore behavior, ecology, and evolution Ithaca: Cornell University Press; 1989. p. 212-41.

Shibata M, Tanaka H, lida S, Abe S, Masaki T, Niiyama K, et al. Synchronized annual seed production by 16 principal tree species in a temperate deciduous forest, Japan. Ecology. 2002;83(6):1727-42.

Silvertown JW. The evolutionary ecology of mast seeding in trees. Biol J Linn Soc. 1980;14(2):235-50.

Smith CC, Hamrick JL, Kramer CL. The advantage of mast years for wind pollination. Am Nat. 1990;136(2):154-66.

Sork VL, Bramble JE. Prediction of acorn crops in three species of north American oaks: Quercus alba, Q. rubra and Q. velutina. Ann Forest Sci. 1993;50:128-36.

SPSS. IBM SPSS statistics for windows, version 24.0. Armonk: IBM Corp; 2017.

SRC. Annual monitoring report in 2008. Seocheon: NIE; 2009. (In Korean).

SRTI. Annual report. Wonju: KNPS; 2014. (In Korean).

The Kyunghyang Shinmun. The last Asiatic black bear dead found; 1983. In Korean.

Yanagisawa N, Fujita N. Different distribution patterns of woody species on a slope in relation to vertical root distribution and dynamics of soil moisture profiles. Ecol Res. 1999:14(2):165-77.

Yang DH, Kim BH, Jung DH, Jeong DH, Jeong WJ, Lee BG. The studies on characteristics of home range size and habitat use of the Asiatic black bear released in Jirisan. Korean J Environ Ecol. 2008;22(4):427-34 (In Korean).

\section{Publisher's Note}

Springer Nature remains neutral with regard to jurisdictional claims in published maps and institutional affiliations.

Ready to submit your research? Choose BMC and benefit from:

- fast, convenient online submission

- thorough peer review by experienced researchers in your field

- rapid publication on acceptance

- support for research data, including large and complex data types

- gold Open Access which fosters wider collaboration and increased citations

- maximum visibility for your research: over $100 \mathrm{M}$ website views per year

At $\mathrm{BMC}$, research is always in progress.

Learn more biomedcentral.com/submissions 